\title{
Pengaruh Brand Personality Terhadap Purchase Intention Produk The Body Shop
}

\author{
Lidia Adetiya Hermanto dan Rodhiah \\ Program Studi Manajemen Fakultas Ekonomi, Universitas Tarumanagara, Jakarta \\ Email: lidia_adetiya@rocketmail.com
}

\begin{abstract}
This research was conducted to prove that Brand personality had a positive influence on the Purchase Intention of The Body Shop consumers. The sampling technique used was purposive sampling with the total of 100 respondents. Data collection using a questionnaire with a Likert Scale. In this study, the analysis technique uses Multiple Regression Analysis, Determination Coefficient and Hypothesis Testing using SPSS 25 Software. The results of this study show that Sincerity, Competence, Excitement, dan Sophistication of Brand personality have a positive effect on the Purchase Intention of The Body Shop consumers. Meanwhile, Ruggedness of Brand personality does not have a positive effect on the Purchase Intention of The Body Shop consumers.
\end{abstract}

Keywords: Brand Personality dan Purchase Intention.

Abstrak: Penelitian ini dilakukan untuk membuktikan Brand personality memiliki pengaruh yang positif untuk Purchase Intention konsumen The Body Shop. Teknik pengambilan sampel yang digunakan adalah convenience sampling dengan jumlah sebanyak 100 responden. Pengumpulan data dengan menggunakan kuisioner dengan Skala Ordinal. Teknik analisis dalam penelitian ini menggunakan Analisis Regresi Berganda, Koefisien Determinasi dan Pengujian Hipotesis dengan menggunakan SPSS 25. Hasil penelitian ini menunjukkan bahwa Sincerity, Competence, Excitement, dan Sophistication dari Brand personality berpengaruh positif terhadap Purchase Intention konsumen The Body Shop, sedangkan Ruggedness dari Brand personality tidak berpengaruh positif terhadap Purchase Intention konsumen The Body Shop.

Kata Kunci: Kepribadian Merek dan Minat Beli.

\section{LATAR BELAKANG}

Persaingan dalam industri kecantikan saat ini semakin kompetitif dalam memenuhi kebutuhan dan keinginan konsumen. Kesadaran konsumen semakin meningkat dalam memilih produk kecantikan yang akan dibelinya, oleh karena itu perusahaan harus menemukan cara yang tepat untuk meraih konsumen.

Pengelolaan merek yang baik di benak konsumen adalah cara yang tepat untuk meraih konsumen. Merek dapat didefinisikan sebagai nama, istilah, tanda, simbol, atau desain, atau kombinasi dari ini, yang dimaksudkan untuk mengidentifikasi barang dan jasa dari satu penjual atau kelompok penjual dan untuk membedakan dari pesaing mereka (Kotler dan Amstrong, 2012). 
Persaingan yang semakin kompetitif mendorong pemasar untuk mengelola merek mereka seunik mungkin di benak konsumen untuk mendorong ketertarikan dan minat beli konsumen. Minat beli atau purchase intention adalah kesediaan konsumen untuk membeli produk atau layanan tertentu. Purchase intention penting untuk memahami perilaku pembelian aktual (Hsu et al., 2012; Wang et al., 2015).

Salah satu cara untuk memilih merek dan meraih konsumen ialah dengan mengaitkan dan mengasosiasikan unsur-unsur kepribadian manusia ke dalam merek, atau yang disebut brand personality atau kepribadian merek untuk membangun hubungan emosional, serta memberikan kemudahan kepada pelanggan untuk mengingat dan mengidentifikasi merek. Brand personality mencerminkan gambaran dari sebuah merek yang tercermin oleh asosiasi merek di benak konsumen. Brand personality terkait erat dengan kepribadian konsumen, sehingga konsumen cenderung memilih merek yang kepribadiannya cocok dengan kepribadian mereka (Tuan et al., 2012). Brand personality adalah bagian penting bagi manajer pemasaran untuk menciptakan diferensiasi di pasar (Sung \& Kim, 2010) dan memiliki pengaruh signifikan terhadap keputusan pembelian konsumen. Brand personality sangat penting bagi konsumen dan pemasaran, karena merupakan penentu utama untuk niat pembelian konsumen.

The Body Shop, adalah perusahaan kosmetik, perawatan tubuh, dan parfum asal Inggris yang didirikan pada tahun 1976 oleh Dame Anita Roddick. Saat ini memiliki 1.000 produk yang dijual di lebih dari 3.049 toko yang dimiliki dan diwaralaba secara internasional di 66 negara. The Body Shop terkenal oleh produk-produknya yang menggunakan zat herbal mulai dari Body Butter, Peppermint Foot Lotion, dan Hemp. Pada tahun 2017, The Body Shop berhasil meraih predikat Top Brand dengan nilai Top Brand Index produk Body Mist dan Body Butter The Body Shop sebesar 14,0\% dan 11,6\%. (topbrand-award.com)

Brand personality adalah faktor pembentuk parameter pertama Top Brand Index, yaitu top of mind brand awareness, maka penting untuk mengetahui tanggapan responden mengenai brand personality produk The Body Shop yang menjadi prediktor signifikan dari kepuasan dan loyalitas pelanggan yang akan mendorong keputusan pembelian aktual.

\section{Tujuan Penelitian}

1. Untuk mengetahui pengaruh sincerity dari brand personality terhadap purchase intention produk The Body Shop.

2. Untuk mengetahui pengaruh competence dari brand personality terhadap purchase intention produk The Body Shop.

3. Untuk mengetahui pengaruh excitement dari brand personality terhadap purchase intention produk The Body Shop.

4. Untuk mengetahui pengaruh sophistication dari brand personality terhadap purchase intention produk The Body Shop.

5. Untuk mengetahui pengaruh ruggedness dari brand personality terhadap purchase intention produk The Body Shop.

\section{KAJIAN TEORI}

Merek adalah nama, istilah, simbol, atau elemen unik lainnya dari suatu produk yang mengidentifikasi produk satu perusahaan dan membedakannya dari pesaing (Solomon, 2012). Arti simbolis suatu merek sering disebut kepribadian merek atau brand personality. 
Kotler \& Keller (2012: 157) menggambarkan brand personality atau kepribadian merek sebagai bauran tertentu dari sifat manusia yang dapat dikaitkan pada merek tertentu.

Aaker menyatakan brand personality terbentuk baik dari karakteristik yang terkait dengan produk maupun yang tidak terkait. Lin, (2010) brand personality berasal dari tiga sumber: yang pertama adalah asosiasi yang dimiliki konsumen dengan merek, kedua, citra yang berusaha dibuat oleh perusahaan, dan yang ketiga adalah tentang atribut produk , misalnya, kategori produk dan saluran distribusi.

Jennifer Aaker dalam Sung, Yongjun, et al, Psychology \& Marketing (2015) mengembangkan kerangka teoritis brand personality dengan menentukan dimensi brand personality. Brand personality diukur oleh lima dimensi. Lima dimensi brand personality tersebut adalah Sincerity, Excitement, Competence, Sophistication and Ruggedness.

1. Sincerity

Menggambarkan keaslian produk, kejujuran dalam kualitas produk dan konsistensi dalam memenuhi kebutuhan dan keinginan konsumen.

2. Excitement

Menggambarkan bagaimana brand dapat memberikan kesenangan kepada konsumen dan dinamis serta imajinatif dalam melakukan inovasi.

3. Competence

Menggambarkan brand yang dapat diandalkan, cakap, dan sukses.

4. Sophistication

Adalah dimensi yang paling sulit dicapai. Dimensi ini berkaitan dengan nilai yang dibentuk oleh brand

image.

5. Ruggedness

Menggambarkan bagaimana suatu brand dapat bertahan ditengah persaingan dengan manfaat brand tersebut dalam menunjang kekuatan produk.

Brand personality sangat penting bagi konsumen dan pemasaran, karena menciptakan karateristik yang berbeda antara berbagai merek (Sung \& Kim, 2010) dan merupakan penentu utama untuk niat pembelian konsumen. Keller (2012: 113) mendefinisikan niat pembelian atau purchase intention sebagai seberapa besar kemungkinan konsumen untuk membeli suatu merek atau seberapa besar kemungkinan untuk berpindah dari satu merek ke merek lainnya. Hsu et al., (2012); Wang et al., (2015) purchase intention penting untuk memahami perilaku pembelian aktual.

Brand personality adalah variabel utama dalam keputusan pembelian konsumen dan merupakan konsep penting dalam diferensiasi merek yang memiliki pengaruh signifikan terhadap keputusan pembelian konsumen Brand personality dianggap sebagai faktor penting untuk kesuksesan merek dalam hal preferensi dan pilihan. Beberapa penelitian menemukan bahwa dimensi brand personality memiliki pengaruh signifikan terhadap pilihan merek, terlepas dari jenis produk.

Berdasarkan hasil penelitian sebelumnya, maka model analisis dari penelitian ini dapat dilihat sebagai berikut: 
Gambar 1. Model Penelitian

Brand Personaling $(X)$

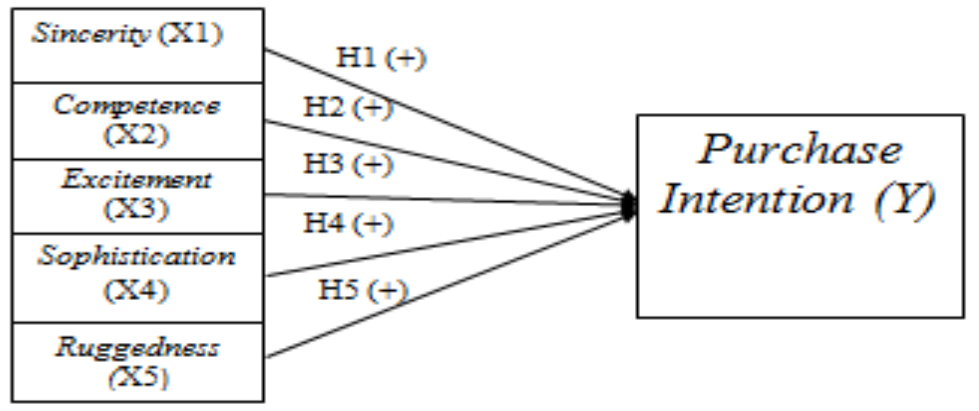

Brand Personality (X). Hipotesa utama pada penelitian ini adalah:

H1: Sincerity dari brand personality berpengaruh positif terhadap purchase intention produk The Body Shop.

H2: Competence dari brand personality berpengaruh positif terhadap purchase intention produk The Body Shop.

H3: Excitement dari brand personality berpengaruh positif terhadap purchase intention produk The Body Shop.

H4: Sophistication dari brand personality berpengaruh positif terhadap purchase intention produk The Body Shop.

H5: Ruggedness dari brand personality berpengaruh positif terhadap purchase intention produk The Body Shop.

\section{METODOLOGI}

Teknik yang digunakan yaitu purposive sampling karena tidak semua sampel memiliki kriteria yang sesuai untuk diteliti. (Sugiyono, 2016: 85) purposive sampling adalah teknik pengambilan sampel dengan beberapa pertimbangan tertentu. Adapun kriteria yang sesuai untuk diteliti sebagai sampel yaitu konsumen produk The Body Shop yang telah menggunakan produk The Body Shop selama minimal satu bulan dan masih berlanjut. Jumlah sampel pada penelitian ini adalah 100 responden, berdasarkan pada pendapat Sugiyono (2016) bahwa ukuran sampel yang layak digunakan dalam penelitian adalah antara 30 sampai dengan 500 dan berdasarkan pada pertimbangan waktu yang relatif lebih singkat dan biaya yang relatif lebih rendah (Nazir, 2011).

Operasionalisasi Variabel. Operasionalisasi variabel adalah proses mendefinisikan variabel dari suatu atribut pada suatu objek yang ditetapkan untuk ditarik kesimpulan. (Sugiyono, 2016:39). Operasionalisasi variabel diperlukan untuk menentukan indikator- 
indikator dari variabel yang terkait dalam penelitian ini. Indikator-indikator tersebut dituangkan dalam tabel dibawah ini.

Table 1. Operasionalisasi Variabel Brand Personality

\begin{tabular}{|c|c|c|c|c|}
\hline Variabel & Indikator & Kode & Skala & Acuan \\
\hline \multirow[t]{3}{*}{$\begin{array}{c}\text { Purchase } \\
\text { Intention }(Y)\end{array}$} & $\begin{array}{l}\text { Bersedia } \\
\text { merekomendasikan } \\
\text { produk kepada orang } \\
\text { lain }\end{array}$ & PI 1 & \multirow[t]{3}{*}{ Ordinal } & \multirow[t]{3}{*}{$\begin{array}{c}\text { Ferdinand } \\
\text { dalam } \\
\text { Sulistyari } \\
(2012: 22)\end{array}$} \\
\hline & $\begin{array}{l}\text { Bersedia membeli } \\
\text { produk. }\end{array}$ & PI 2 & & \\
\hline & $\begin{array}{l}\text { Memiliki keinginan } \\
\text { untuk mencari tau } \\
\text { informasi mengenai } \\
\text { produk. }\end{array}$ & PI 3 & & \\
\hline
\end{tabular}

Tabel 2. Operasionalisasi Variabel Purchase Intention 


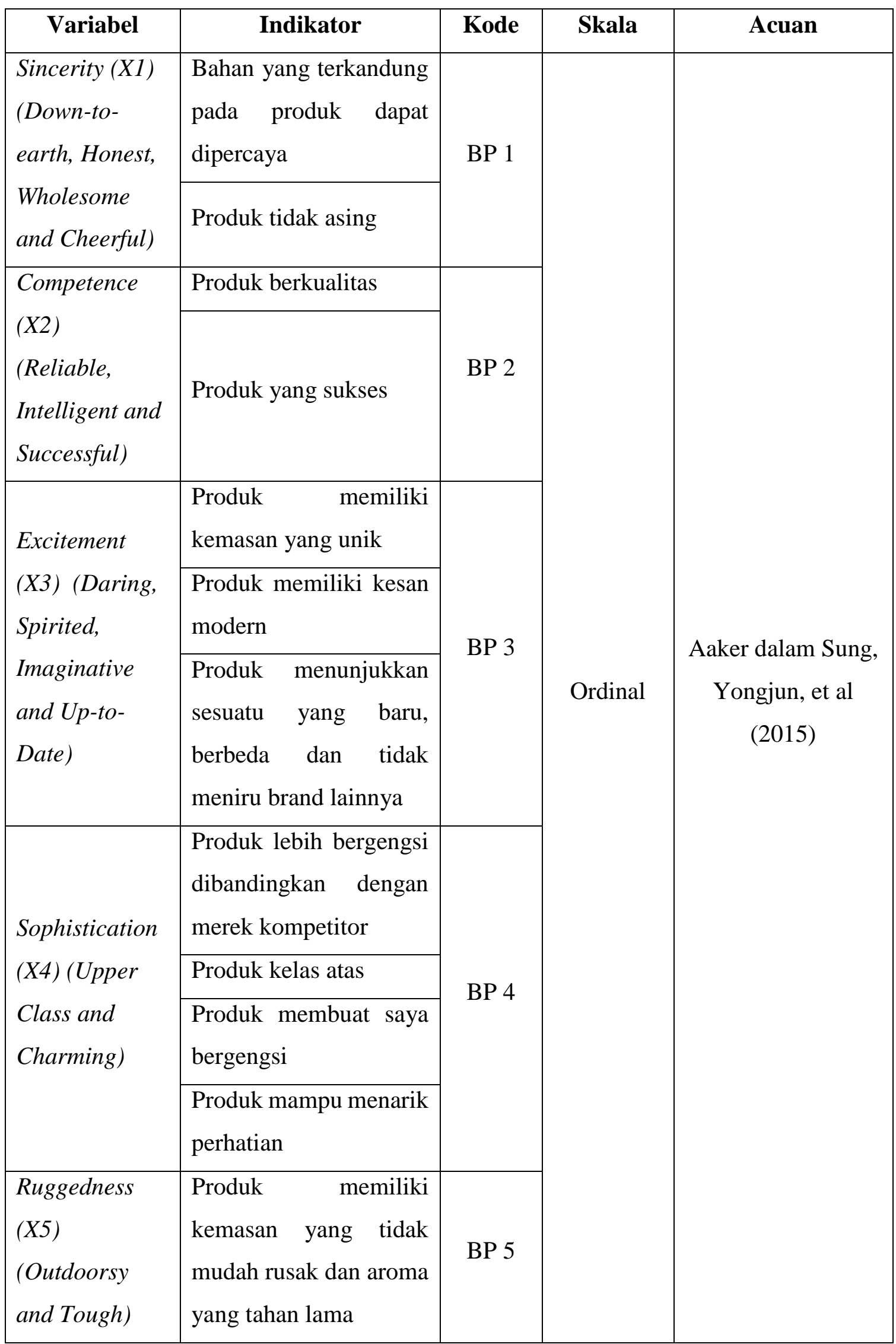




\begin{tabular}{|l|l|l|l|l|}
\hline & $\begin{array}{l}\text { Produk tidak kuno dan } \\
\text { mengikuti } \\
\text { perkembangan }\end{array}$ & & & \\
\hline
\end{tabular}

Penentuan subjek penelitian dilakukan dengan cara purposive sampling. Sugiyono, (2012 : 68) Purposive sampling adalah non-probability sample atau teknik pengambilan sampel yang dipilih berdasarkan karakteristik populasi dan tujuan penelitian. Dalam penelitian ini, peneliti menjadikan The Body Shop sebagai industri yang dijadikan penelitian. Maka, subjek penelitian dalam penelitian ini adalah 100 responden atau konsumen The Body Shop. Objek penelitian yang diteliti adalah Sincerity (X1), Competence (X2), Excitement (X3), Sophictication (X4), dan Ruggedness (X5) serta pengaruhnya terhadap Purchase Intention (Y).

Hasil Uji Analisis Data. Berdasarkan hasil pengolahan uji reliabilitas dan validitas menunjukkan bahwa setiap item dinyatakan reliabel dan valid. Dengan demikian, hasil uji analisis data disajikan sebagai berikut.

Uji ANOVA atau Uji F. Dari tabel 3 di bawah, dapat diketahui bahwa nilai signifikan adalah 0.000. Nilai signifikan ini lebih kecil dari 0,05 sehingga Ho ditolak. Dengan demikian dapat disimpulkan bahwa variabel independen secara bersama-sama mempengaruhi variabel dependen.

Tabel 3. Hasil Uji ANOVA atau Uji F

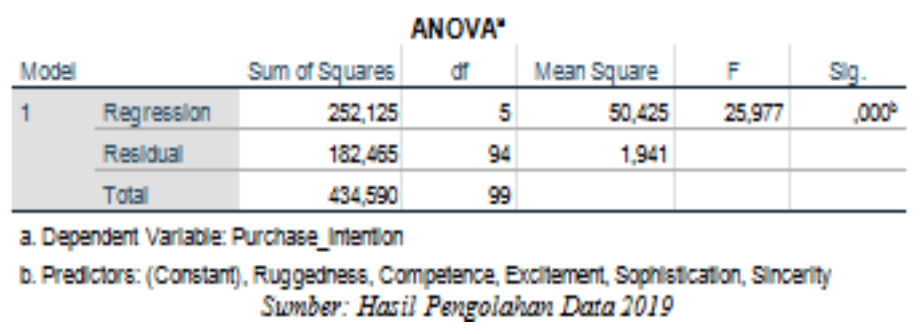

Hasil Uji Parsial. Berdasarkan tabel 1.4 di bawah, diketahui bahwa tingkat signifikan variabel Sincerity adalah 0,030 dimana itu lebih kecil dari 0,05 sehingga dapat diambil kesimpulan bahwa $\mathrm{H} 1$ tidak ditolak

Berdasarkan tabel 1.4 di bawah, diketahui bahwa tingkat signifikan variabel Competence adalah 0,028 dimana itu lebih kecil dari 0,05 sehingga dapat diambil kesimpulan bahwa $\mathrm{H} 2$ tidak ditolak.

Berdasarkan tabel 1.4 di bawah, diketahui bahwa tingkat signifikan variabel Excitement adalah 0,004 dimana itu lebih kecil dari 0,05 sehingga dapat diambil kesimpulan bahwa $\mathrm{H} 3$ tidak ditolak.

Berdasarkan tabel 1.4 di bawah, diketahui bahwa tingkat signifikan variabel Sophistication adalah 0,000 dimana itu lebih kecil dari 0,05 sehingga dapat diambil kesimpulan bahwa $\mathrm{H} 4$ tidak ditolak. 
Berdasarkan tabel 4 di bawah, diketahui bahwa tingkat signifikan variabel Ruggedness adalah 0,906 dimana itu lebih besar dari 0,05 sehingga dapat diambil kesimpulan bahwa H5 ditolak.

Tabel 4. Hasil Uji T

\begin{tabular}{|c|c|c|c|c|c|c|}
\hline \multirow[b]{2}{*}{ Model } & & \multicolumn{2}{|c|}{ Unstandardzed Coefticlents } & \multirow{2}{*}{$\begin{array}{c}\text { Standardized } \\
\text { Coettclents } \\
\text { Beta }\end{array}$} & \multirow[b]{2}{*}{$\mathrm{t}$} & \multirow[b]{2}{*}{ Sig. } \\
\hline & & B & Std. Error & & & \\
\hline \multirow[t]{6}{*}{1} & (Constant) & $-4,296$ & 1,652 & & $-2,600$ & .011 \\
\hline & Sincerity & .481 & .218 & .197 & 2,202 & .030 \\
\hline & Competence & .440 & .197 & .193 & 2,231 & .028 \\
\hline & Excliement & 302 & .103 & .255 & 2,937 & .004 \\
\hline & Sophistication & .245 & .052 & .345 & 3,957 & .000 \\
\hline & Ruggednes5 & 021 & 179 & .010 & 119 &, 905 \\
\hline
\end{tabular}

Sumber: Hasil Pengolahan Data 2019

\section{Hasil Uji Koefisien Determinasi (Adjusted $\mathbf{R}^{\mathbf{2}}$ )}

Dari tabel 5 di bawah, dapat dilihat Adjusted $R$ Square sebesar 0,558. Jadi dapat disimpulkan bahwa sebesar 0,558 atau 55,8\% dari variabel Purchase Intention dapat dijelaskan oleh variabel Sincerity, Competence, Excitement, Sophistication dan Ruggedness dari Brand Personality. Dan sisanya sebesar 0,442 dapat dijelaskan oleh variabel lain.

Tabel 5. Hasil Uji Koefisien Determinasi

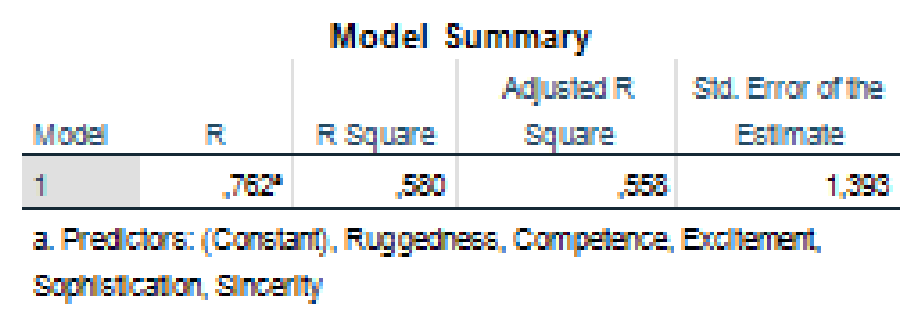

Sumber: Hasil Pengolahan Data 2019

\section{DISKUSI}

Berdasarkan hasil uji analisis data, diketahui bahwa terdapat 4 hipotesis yang didukung yaitu $\mathrm{H} 1, \mathrm{H} 2, \mathrm{H} 3$, dan $\mathrm{H} 4$, sedangkan 1 hipotesis tidak didukung yaitu $\mathrm{H} 5$. Berdasarkan hasil analisis data yang telah dilakukan, peneliti perlu membahas hasil hipotesis dalam penelitian ini.

Hipotesis pertama, menyatakan bahwa sincerity dari brand personality merupakan pengaruh yang positif dan signifikan untuk purchase intention bagi konsumen The Body Shop. Temuan ini sejalan dengan penelitian yang dilakukan oleh Saeid et al., (2017) yang menunjukkan bahwa sincerity memiliki dampak positif dan signifikan terhadap purchase intention.

Hipotesis kedua, menyatakan bahwa competence dari brand personality merupakan pengaruh yang positif dan signifikan untuk purchase intention bagi konsumen The Body Shop. Temuan ini sejalan dengan penelitian yang dilakukan oleh Matzler, Kurt, et al (2016) 
yang menyatakan bahwa competence memiliki dampak positif dan signifikan terhadap purchase intention.

Hipotesis ketiga, menyatakan bahwa excitement dari brand personality merupakan pengaruh yang positif dan signifikan untuk purchase intention bagi konsumen The Body Shop. Temuan ini sejalan dengan penelitian yang dilakukan oleh Akin, M. (2011) yang menunjukkan bahwa excitement adalah faktor yang paling memiliki pengaruh signifikan dan positif terhadap purchase intention.

Hipotesis keempat, menyatakan bahwa sophistication dari brand personality merupakan pengaruh yang positif dan signifikan untuk purchase intention bagi konsumen The Body Shop. Temuan ini sejalan dengan penelitian yang dilakukan oleh Vahdati, Hojjat; Mousavi Nejad, Seyed Hadi (2016) yang menunjukkan bahwa sophistication secara signifikan berpengaruh terhadap purchase intention.

Hipotesis kelima, menyatakan bahwa ruggedness dari brand personality bukan merupakan pengaruh yang positif dan signifikan untuk purchase intention bagi konsumen The Body Shop. Temuan ini sejalan dengan penelitian yang dilakukan oleh Toldos-Romero \& Orozco-Gómez, (2015) yang menunjukkan bahwa ruggedness bukan merupakan prediktor positif terhadap purchase intention.

\section{KESIMPULAN}

Berdasarkan hasil penelitian yang telah dilakukan peneliti mengenai pengaruh variabel bebas atau variabel independen, variabel Brand Personality yaitu sincerity, competence, excitement, sophistication dan ruggedness terhadap variabel terikat atau variabel dependen yaitu Purchase Intention terhadap konsumen The Body Shop, maka dapat disimpulkan bahwa sincerity, competence, excitement, dan sophistication merupakan pengaruh yang positif dan signifikan untuk purchase intention bagi konsumen The Body Shop, sedangkan ruggedness bukan merupakan pengaruh yang positif dan signifikan untuk purchase intention bagi konsumen The Body Shop.

Saran. Berdasarkan dari penelitian ini, peneliti memiliki saran yang diharapkan dapat bermanfaat untuk para pengusaha dan peneliti berikutnya, saran-saran tersebut antara lain:

1. Peneliti menyarankan kepada perusahaan hendaknya mengenalkan produknya dengan strategi yang tepat, dengan memperhatikan kaidah-kaidah komunikasi pemasaran yang efektif.

2. Peneliti menyarankan kepada perusahaan The Body Shop untuk meningkatkan kualitas produknya, mempertahankan kemasan produk tetap unik dan terus berinovasi, menunjukkan sesuatu yang berbeda dari brand lainnya.

3. Peneliti menyarankan kepada perusahaan untuk mempertahankan desain yang modern pada produknya agar lebih meningkatkan kesan citra merk yang lebih kuat.

4. Peneliti menyarankan kepada peneliti selanjutnya untuk menambah variabel lain yang dapat berpengaruh terhadap minat pembelian atau purchase intention sehingga diharapkan dengan penambahan variabel yang semakin banyak maka hasil penelitian akan semakin akurat.

5. Peneliti menyarankan kepada peneliti selanjutnya untuk mengaitkan variabel brand personality dengan variabel lainnya sehingga hasil penelitian dapat memperkaya pengetahuan mengenai teori-teori yang berkaitan khususnya pada bidang manajemen pemasaran. 


\section{DAFTAR PUSTAKA}

Ghozali, Imam. (2012). Aplikasi Analisis Multivariate dengan Program IBM SPSS. Yogyakarta: Universitas Diponegoro.

Ghozali, Imam. (2016). Aplikasi Analisis Multivariete Dengan Program IBM SPSS 23 (Edisi 8). Cetakan ke VIII. Semarang : Badan Penerbit Universitas Diponegoro.

Hsu, C., Chang, K. and Chen, M.C. (2012), "The impact of website quality on customer satisfaction and purchase intention: perceived playfulness and perceived flow as mediators", Information Systems and e-Business Management, Vol. 10 No. 4, pp. 549570.

Kotler, Philip dan Armstrong, Gary. (2012). Principles of Marketing. New Jersey: Prentice Hall.

Lin, L. Y. (2010). The Relationship of Consumer Personality Trait. Brand Personality and Brand Loyalty: An Empirical Study of Toys and Video Games Buyers. Journal of Product \& Brand Management, 9(1), 4-17.

Moh Nazir, (2011). Metode Penelitian. Cetakan 6. Bogor: Penerbit Ghalia Indonesia.

Sekaran, Uma \& Bougie, Roger (2013). Research Methods for Business: A Skill- Building Approach. Sixth Edition. United Kingdom: John Wiley \& Sons Ltd.

Solomon, Michael R. (2012). Consumer Behavior: Buying, Having, Being, Edition 10. New Jersey: Pearson Addison Wesley.

Sugiyono. (2012). Metode Penelitian Kuantitatif Kualitatif dan R\&D. Bandung: Alfabeta.

Sugiyono. (2016). Metode Penelitian Kuantitatif Kualitatif dan Kombinasi (Mixed Methods). Bandung: Alfabeta.

Sung, Y., \& Kim, J. (2010). Effects of brand personality on brand trust and brand affect. Psychology and Marketing, 27(7), 6 Sung, Y., Choi, S. M., Ahn, H., \& Song, Y. A. (2015). Dimensions of luxury brand personality: Scale development and validation. Psychology \& Marketing, 32(1), 121-132. 39-661.

Tuan, L. Y., Tat, H. H., Shamsuddin, A. S., Rasli, A. M., \& Jusoh, A. (2012). Potential of Brand Personality: Attachment Styles as Moderator. American Journal of Business and Management, 1(3), 34-42.

Wang, L., Law, R., Guillet, B.D., Hung, K. and Fong, D.K.C. (2015), "Impact of hotel website quality on online booking intentions: eTrustas a mediator", International Journal of Hospitality Management, Vol. 47 No. 1, pp. 108-115 